\title{
Organic compounds in water extracts of coal: links to Balkan endemic nephropathy
}

\author{
S. V. M. Maharaj · W. H. Orem • C. A. Tatu • \\ H. E. Lerch III • D. N. Szilagyi
}

Received: 26 December 2012/ Accepted: 2 March 2013/Published online: 21 March 2013

(C) The Author(s) 2013. This article is published with open access at Springerlink.com

\begin{abstract}
The Pliocene lignite hypothesis is an environmental hypothesis that has been proposed to explain the etiology of Balkan endemic nephropathy (BEN). Aqueous leaching experiments were conducted on a variety of coal samples in order to simulate groundwater leaching of organic compounds, and to further test the role of the Pliocene lignite hypothesis in the etiology of BEN. Experiments were performed on lignite coal samples from endemic BEN areas in Romania and Serbia, and lignite and bituminous coals from nonendemic regions in Romania and the USA. Room temperature, hot water bath, and Soxhlet aqueous extraction experiments were conducted between 25 and $80^{\circ} \mathrm{C}$, and from 5 to 128 days in duration. A greater number of organic compounds and in higher concentrations were present in all three types of leaching
\end{abstract}

S. V. M. Maharaj · W. H. Orem · C. A. Tatu

H. E. Lerch III

U.S. Geological Survey, Reston, VA 20192, USA

S. V. M. Maharaj ( $₫)$

Center for Research on Environmental Medicine,

New Market, MD 21774, USA

e-mail: svmm@environmed.org

C. A. Tatu

Department of Biology, University of Medicine and Pharmacy Timisoara, Timisoara, Romania

D. N. Szilagyi

Department of Pathology, County Hospital Timisoara,

Timisoara, Romania experiments involving endemic area Pliocene lignite samples compared to all other coals examined. A BEN causing molecule or molecules may be among phenols, PAHs, benzenes, and/or lignin degradation compounds. The proposed transport pathway of the Pliocene lignite hypothesis for organic compound exposure from endemic area Pliocene lignite coals to well and spring drinking water, is likely. Aromatic compounds leached by groundwater from Pliocene lignite deposits in the vicinity of endemic BEN areas may play a role in the etiology of the disease. A better understanding of organic compounds leached by groundwater from Pliocene lignite deposits may potentially lead to the identification and implementation of effective strategies for the prevention of exposure to the causative agent(s) for BEN, and in turn, prevention of the disease.

Keywords BEN · Coal geochemistry ·

Environmental etiology · GC/MS · Groundwater simulation - Leaching experiments · Low-rank coal · Medical geology $\cdot$ Pliocene lignite hypothesis

\section{Introduction}

Most of the world's energy is provided by fossil fuels, and coal is the world's most abundant fossil fuel with reserves substantially greater than those of oil and natural gas (Kavouridis and Koukouzas 2008). "Lignite" ranks in between peat and subbituminous in the sequential transformation from decomposed plant 
matter to anthracite (Whitehurst 1978). Balkan Peninsula countries rely heavily on lignite to meet their energy demands, as for example, it constitutes more than $85 \%$ of the total coal reserves in Bulgaria (Siskov 1997), and generates over $60 \%$ (Kavouridis and Koukouzas 2008) to more than $75 \%$ (Iordanidis and Georgakopoulos 2003) of the total electric power output in Greece.

Coal use, however, has been associated with adverse human health effects (Wilson et al. 1980; Finkelman et al. 2002), and large health costs (Barbir and Veziroglu 1992). Coal quality parameters, for example, organic chemistry and leachability, have been identified as data needed for evaluating the potential human health impacts of coal (Finkelman and Gross 1999), as many adverse human health effects may be in part due to the mobilization of organic compounds (Swaine and Goodarzi 1995; Mumford et al. 1987, 1995; Mastrangelo et al. 1996; Finkelman et al. 1999). Organic compounds may be mobilized from coal into drinking water by groundwater, and by surface water, for example, during mining, and during transportation and storage prior to electric power plant utilization. Leached organic compounds from coal may also be hazardous to human health due to their potential to contribute to the formation of toxic compounds in the environment. Potential human health risks of organic compounds leached from coal include endocrine disruption, nephrotoxicity, and cancer (Gaitan et al. 1993; Bunnell et al. 2006; Finkelman 2007).

Balkan endemic nephropathy

Balkan endemic nephropathy (BEN) is a chronic, tubulointerstitial renal disease often accompanied by urothelial cancer (Radovanovic and Krajinovic 1979; Vukelic et al. 1992), geographically confined to countries of the Balkan Peninsula with endemic locations in central and southeastern Serbia, southwestern Romania, northwestern Bulgaria, southeastern Croatia, and parts of Bosnia and possibly Kosovo (Fig. 1; Craciun and Rosculescu 1970; Feder et al. 1991; Ceovic et al. 1992). The disease occurs in rural villages, typically in alluvial valleys that contain a main drainage tributary of the Danube River. Prevalence of BEN in endemic areas is $2-10 \%$ (Ceovic et al. 1992), lethality is nearly $100 \%$ (Ceovic et al. 1992), and over 100,000 individuals may be at risk for developing the disease (Plestina 1992).
Hypotheses that have been proposed for the etiology of BEN include: lead contamination of wheat flour (Danilovic et al. 1957); heavy metals in water or foodstuffs (Gaon et al. 1962; Piscator et al. 1984; Wedeen 1991); autoimmunity (Craciun and Rosculescu 1970); aristolochic acid from Aristolochia clematitis seeds (Ivic 1970; Hranjec et al. 2005; Grollman and Jelakovic 2007); bacteria and viruses (Apostolov et al. 1975; Georgescu et al. 1976; Bozic et al. 1995); ochratoxin A, a fungal mycotoxin (Petkova-Bocharova et al. 1988); Pliocene lignites (Feder et al. 1991); selenium deficiency (Maksimovic 1991; Mihailovic et al. 1992); and genetic causes (Pavlovic et al. 1991, 2008; Toncheva et al. 1991; Toncheva and Dimitrov 1996). Strengths and limitations of hypotheses have been reviewed elsewhere (Plestina 1992; Stefanovic 1998; Tatu et al. 1998; Toncheva et al. 1998; Radovanovic 2002; Voice et al. 2006a, b; Long and Voice 2007; Gluhovschi et al. 2011a, b), but evidence from many studies (Batuman 1991; Morozov et al. 1991; Plestina 1992; Stefanovic 1998; Toncheva et al. 1998; Tatu et al. 1998; Radovanovic 2002; Stefanovic et al. 2006; Voice et al. 2006a) favors the involvement of one or more environmental factors, for example, exposure to Pliocene lignite coal deposits, in the etiology of the disease.

\section{Pliocene lignite hypothesis}

The Pliocene lignite hypothesis posits that BEN is caused by long-term exposure to low concentrations of aromatic hydrocarbons and other toxic organic compounds leaching into well and spring water via groundwater from low-rank coals, that is, Pliocene lignites, found in the vicinity of endemic settlements (Feder et al. 1991; Tatu et al. 1998; Orem et al. 1999). The rural population uses the well and spring water almost exclusively (Tatu et al. 2000a) for drinking, cooking, bathing, irrigation, and other purposes. The low concentration of the toxic organic compounds may account for the slow development (i.e., a 10-30year subclinical incubation period) of the disease, and may possibly be linked to the high association of BEN with upper urinary tract carcinomas (Tatu et al. 1998; Orem et al. 1999), a form of cancer also with a much higher incidence in individuals from endemic versus nonendemic areas (Radovanovic and Krajinovic 1979; Cukuranovic et al. 1991; Petronic et al. 1991).

Limited information is available on the distribution of the coal deposits and the hydrology in the endemic 
Fig. 1 Map showing the distribution of Balkan endemic nephropathy regions (adapted after Tatu et al. 1998)

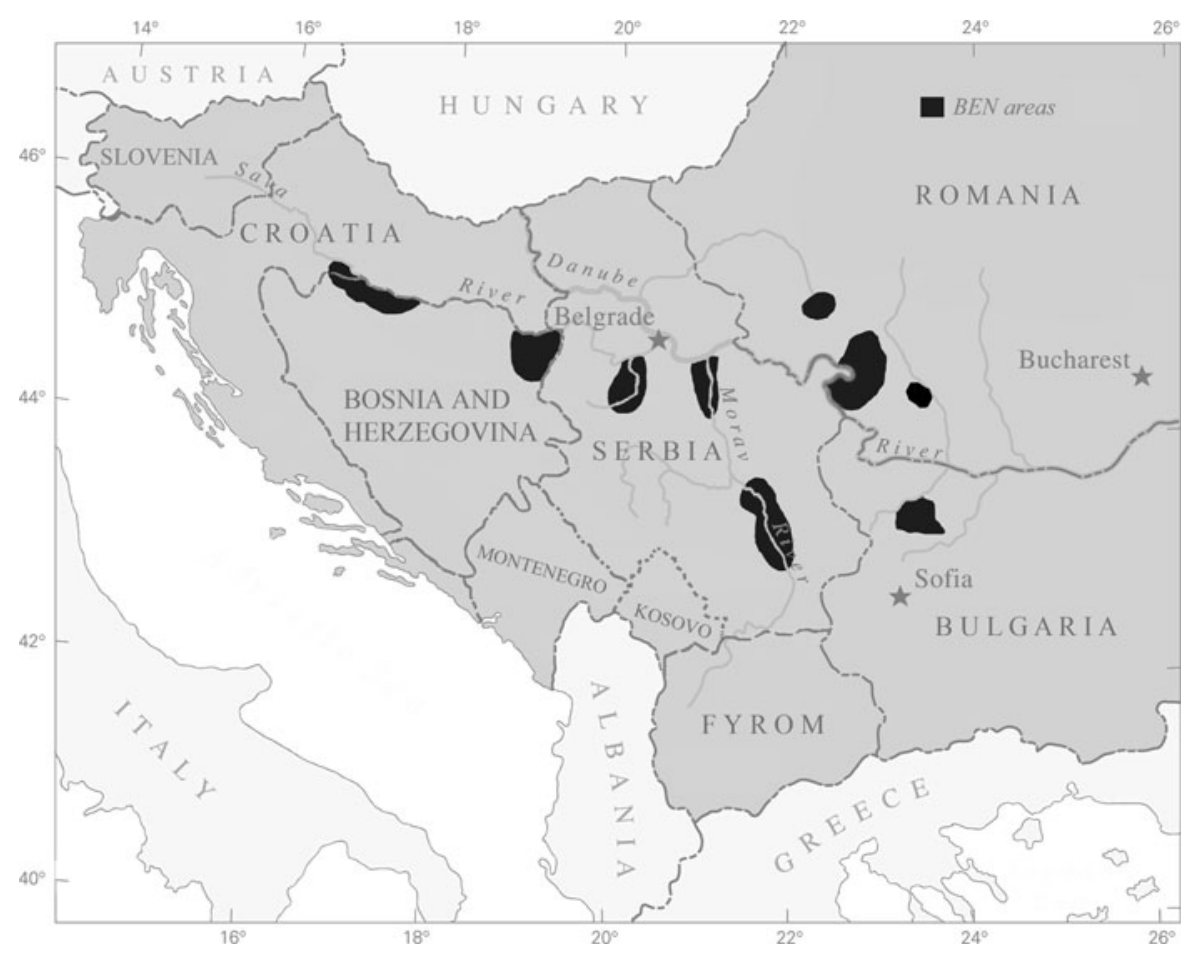

areas (Radovanovic and Peric 1979; Feder et al. 1991, 2002; Tatu et al. 2000a). Geologic structure differs from one village to another (Craciun and Rosculescu 1970; Feder et al. 1991), but the bedrock adjacent to all endemic areas in the former Yugoslavia contain coal (Feder et al. 1991). In Romania and the former Yugoslavia, an 80-100-m column of Tertiary sediments would typically contain 10-15 Pliocene lignite layers (Feder et al. 2002). The mainly Pliocene age (1.8-5.3 million years old) coal layers in the endemic region are close to the surface, beginning $220-250 \mathrm{~m}$ in elevation at the western part of the coalfield, and decreasing to less than $100 \mathrm{~m}$ in elevation as they extend to the east/southeast/northeast. Therefore, the endemic villages may be located below the coal layers (located in the surrounding hills), or overlying the layers, and there are instances of wells penetrating through the coal layers, for example, in the endemic villages of Poroina, Romania and Vreoci, Serbia. In addition, in Romania, coal mines are in close proximity, that is, $<1 \mathrm{~km}$, to several endemic villages, for example, Erghevitza, Husnicioara, Livezile, Pietris, and Prunisor (Tatu et al. 2000a). In Bulgaria, extensive coal deposits occur north and south of the endemic region, and the endemic region is geologically defined by Pliocene sediments (Feder et al. 2002).
Furthermore, in 2009, we discovered the presence of at least two types of coal in the Bulgarian endemic areas, one being a low-rank lignite, very similar to Romanian and Serbian endemic Pliocene lignites.

The well and spring water in endemic regions is largely supplied by aquifers with a relatively fast flow rate, for example, from rain. However, the underground transport pathway may be highly variable (Niagolova et al. 2005). The aquifers are shallow, as evidenced in part by the high nitrate levels (Orem et al. 2002; Niagolova et al. 2005), an indicator of surface contamination [that likely originate from fertilizers used by the villagers (Orem et al. 2002)]. In Romania, average depth-to-water of open shallow wells and springs in endemic villages is $0-10 \mathrm{~m}$ (Tatu et al. 2000a), and in Bulgaria it is $<15 \mathrm{~m}$ (Niagolova et al. 2005). Given the relatively fast flow rate and the shallowness of the aquifers, it is unlikely that the well and spring water is supplied to a significant extent by, for example, fossil aquifers and paleowater.

\section{Previous studies}

Inorganic geochemical analyses of well and spring water samples from Romania have shown no significant differences between endemic and nonendemic 
regions (Orem et al. 2002, 2004), but for organic substances the situation is different. For example, a greater number of organic compounds (Goldberg et al. 1994) and in higher concentrations (Orem et al. 1999) were shown to be present in endemic versus nonendemic water samples, with well and spring water samples from endemic villages containing more aliphatic and aromatic compounds [many of which are potentially toxic (including, nitrogen-, oxygen-, and sulfur-containing heterocyclic compounds, aromatic amines, and phenols)], and in higher concentrations than water samples from nonendemic villages (Orem et al. 2002, 2004). Also, methanol extracts of lignite samples showed that endemic Pliocene coals possessed a complexity that was not matched by any nonendemic lignites, including a nonendemic Pliocene age lignite (Orem et al. 2002; Tatu et al. 2003), or other coals (Tatu et al. 2000a, b; Feder et al. 2002). In addition, human mesenchymal stem cells exposed to a water extract of an endemic area Pliocene lignite showed increased cellular proliferation and differentiation compared to the control (Suciu et al. 2005), and human kidney cells exposed to concentrated highmolecular-weight organic compounds from an endemic village water sample showed excess cell death or proliferation compared to controls (Bunnell et al. 2007).

However, a number of criticisms about the Pliocene lignite hypothesis, and many of the above previous studies have been raised (Pfohl-Leszkowicz et al. 2002; Voice et al. 2002, 2006a, b; Arlt et al. 2007; Gluhovschi et al. 2011a, b). For example, evaluations of the research that supports the Pliocene lignite hypothesis concluded that studies have not moved beyond a weak topographical association (Voice et al. 2006a, b). Demonstration of a cause-and-effect relationship was considered far away (Radovanovic 2002), in part because the source of the organic compounds in the well and spring water has been unconfirmed (Orem et al. 2004), and moreover, the exposure pathway has been deemed unlikely (Voice et al. 2006b).

Some limitations of the Pliocene lignite hypothesis have been addressed in the literature, for example, regarding the topographical association between the deposits and endemic BEN areas (Tatu et al. 1998; Finkelman et al. 2002). A comprehensive compilation of the possible limitations of the hypothesis, including whether other environmental agents may be more plausible as etiological factors than exposure to Pliocene lignites, for example, aristolochic acid from A. clematitis seeds (Ivic 1970; Hranjec et al. 2005; Grollman and Jelakovic 2007), with each limitation addressed in turn, is presented elsewhere (Maharaj 2013).

In addition, studies on Pliocene and other lignites from the Balkans, for example, Bulgaria (Stefanova et al. 2002), Greece (Siavalas et al. 2007), and Slovenia (Bechtel et al. 2003) have included organic geochemical analysis, but few studies have been conducted to identify organic compounds and their concentrations leached by water from coal experiments (McElmurry and Voice 2004). For example, experiments using coal samples (Koukouzas et al. 2010), including lignites (Baba and Kaya 2004; Koukouzas et al. 2009) have typically not included leaching experiments, and studies that have addressed the leaching of lignite samples (Orem et al. 1999; Wang et al. 2008; Izquierdo et al. 2011) have typically not included the identification of organic compounds.

\section{This study}

Therefore, we have conducted aqueous leaching experiments on a variety of coal samples, including Pliocene lignites from endemic BEN areas, in order to simulate groundwater leaching of organic compounds, and to further test the role of the Pliocene lignite hypothesis in the etiology of BEN. Herein, presented for the first time, is the identification and concentration of organic compounds leached by water from endemic (and nonendemic) area coal samples under various experimental conditions. Results provide direct evidence of the water-soluble, water-leachable, and water-extractable organic compounds, and therefore, evidence for also possibly linking the organic compounds present in the well and spring drinking water from endemic locations to the proximal Pliocene lignite coal deposits. Preliminary results only have been published (Orem et al. 2002, 2004; Finkelman et al. 2002; Tatu et al. 2003).

This study will add to the increasing body of knowledge in the re-emerging discipline known as medical geology (Finkelman et al. 2005; Selinus 2007), and may be used as part of an approach for potentially linking BEN in other areas, and/or other diseases, to organic compounds leached from coal by groundwater. 


\section{Materials and methods}

Samples

The coal samples used in this study (Table 1) were Pliocene lignites from endemic BEN areas of Romania and Serbia, lignite and bituminous coals from nonendemic areas of Romania, and lignite and bituminous coals from nonendemic areas in the USA. Coal samples from Romania and Serbia were collected fresh from open pit and underground mines. Coal samples from the USA were obtained from the US Geological Survey (USGS) in Reston, VA, USA. All lignite coal samples available at the time of the experiments were used. Sample locations from Romania and Serbia were selected based on their endemic character, as determined from medical records obtained from the Drobeta Turnu Severin County Hospital in Romania, and in consultation with nephrophologists treating BEN patients in Serbia. Endemic regions are defined as areas with described, that is, known BEN cases (e.g., documented in medical records or the literature) and/or a family history of BEN. Nonendemic regions are defined as areas without any described BEN cases or a family history of the disease.

\section{Aqueous leaching experiments}

Standard clean laboratory techniques for organic analyses were followed in cleaning all glassware and laboratory apparatus, and in sample preparation, analysis, and storage, including baking $\left(450{ }^{\circ} \mathrm{C}\right)$ or rinsing of glassware with pesticide grade dichloromethane to remove any organic contaminants. Three types of experiments (Table 2) that simulate groundwater leaching of coals were performed: room temperature $\left(25^{\circ} \mathrm{C}\right)$, hot water bath $\left(75^{\circ} \mathrm{C}\right)$, and
Soxhlet experiments $\left(80{ }^{\circ} \mathrm{C}\right)$. Room temperature and hot water bath experiments were performed to approximate unheated and heated groundwater, respectively. As it would not have been feasible to leach organics from coal for decades in the laboratory (in order to mimic the subclinical exposure period of the disease), Soxhlet experiments were performed to accelerate leaching of organics to approximate groundwater leaching over long periods of time. However, due to the temperature condition used, hot water bath experiments would also likely accelerate leaching of organics, and therefore, this group of experiments may also be considered as approximating groundwater leaching over long periods of time, but to a lesser extent than Soxhlet experiments.

Ten grams of coal were used in each experiment. Samples were grounded to $<297 \mu \mathrm{m}$ grain size before leaching. One endemic area sample (i.e., Husnicioara) was also prepared as 5-10 mm diameter pebbles in order to compare possible differences in organic compound extractability as a function of grain size. Room temperature and hot water bath samples were placed in clean beakers with 100 and $250 \mathrm{ml}$ milliQ water (i.e., 18 megaohms), respectively. Soxhlet coal samples were contained in Whatman cellulose extraction thimbles, and placed in Soxhlets with $250 \mathrm{ml}$ milliQ water.

No attempt was made to mimic the elements or compounds present in natural groundwater in the water used for experiments, in order to ensure that results could be directly linked to experimental conditions, as possible side interactions could have occurred due to the presence of introduced solutes. In addition, distilled, deionized, and/or demineralized water has been commonly used in the laboratory in coal leaching experiments (Praharaj et al. 2002; Wang et al. 2008; Chakraborty and Mukherjee 2009; Ruhl et al. 2010; Yuan et al. 2010), including with lignite

Table 1 Coal sample characteristics

\begin{tabular}{lllll}
\hline Sample & Rank & Age & Locality & Region \\
\hline Bpesyn & Lignite & Pliocene & Serbia & Endemic \\
Husnicioara & Lignite & Pliocene & Husnicioara, Romania & Endemic \\
Husnicioara pebbles & Lignite & Pliocene & Husnicioara, Romania & Endemic \\
Brad & Lignite & Miocene & Transylvania, Romania & Nonendemic \\
Haegel & Lignite & Paleocene & North Dakota, USA & Nonendemic \\
Doman & Bituminous & Carboniferous & Romania & Nonendemic \\
IRC \#36 & Bituminous & Carboniferous & Maryland, USA & Nonendemic \\
\hline
\end{tabular}

$I R C$ internal reference coal. All sample grain sizes are $<297 \mu \mathrm{m}$ except for Husnicioara pebbles which are 5-10 mm in diameter 
Table 2 Experimental runs and conditions

\begin{tabular}{|c|c|c|c|}
\hline Sample \# & Sample & Temp. $\left({ }^{\circ} \mathrm{C}\right)$ & Time (days) \\
\hline Rt-A-1 & IRC \#36 & 25 & 39 \\
\hline Rt-A-2 & IRC \#36 & 25 & 39 \\
\hline Rt-A-4 & Husnicioara pebbles & 25 & 39 \\
\hline Rt-C-4 & Doman & 25 & 97 \\
\hline Rt-C-5 & Haegel & 25 & 97 \\
\hline Rt-C-2 & Brad & 25 & 97 \\
\hline Rt-C-3 & Brad & 25 & 97 \\
\hline Rt-C-1 & Bpesyn & 25 & 97 \\
\hline Rt-B-1 & IRC \#36 & 25 & 128 \\
\hline Rt-B-2 & IRC \#36 & 25 & 128 \\
\hline Rt-B-3 & Husnicioara & 25 & 128 \\
\hline Rt-B-4 & Husnicioara pebbles & 25 & 128 \\
\hline Hb-A-1 & IRC \#36 & 75 & 5 \\
\hline $\mathrm{Hb}-\mathrm{A}-2$ & IRC \#36 & 75 & 5 \\
\hline Hb-A-6 & Doman & 75 & 5 \\
\hline $\mathrm{Hb}-\mathrm{A}-5$ & Brad & 75 & 5 \\
\hline $\mathrm{Hb}-\mathrm{A}-3$ & Husnicioara & 75 & 5 \\
\hline Hb-A-8 & Husnicioara pebbles & 75 & 5 \\
\hline Sx-F-1 & IRC \#36 & 80 & 5 \\
\hline Sx-F-2 & IRC \#36 & 80 & 5 \\
\hline Sx-F-7 & Doman & 80 & 5 \\
\hline Sx-F-8 & Haegel & 80 & 5 \\
\hline Sx-F-6 & Brad & 80 & 5 \\
\hline Sx-F-5 & Bpesyn & 80 & 5 \\
\hline Sx-F-3 & Husnicioara & 80 & 5 \\
\hline Sx-F-4 & Husnicioara pebbles & 80 & 5 \\
\hline
\end{tabular}

$R t$ room temperature, $H b$ hot water bath, $S x$ Soxhlet

samples (Tatu et al. 1998; Orem et al. 1999; McElmurry and Voice 2004; Izquierdo et al. 2011), and to study organic compounds (Koopmans et al. 1997; Kruger et al. 2012) or metals (Prokop et al. 2003) from other geologic material. Furthermore, laboratory experiments that simulated groundwater transport have often not mimicked aquifer ion composition (Bales et al. 1997; Prommer et al. 2008; Jung et al. 2009; Wright et al. 2010; Zhang et al. 2010), particularly when the species of the metals are not known (Christensen and Christensen 1999), as is the case here. Finally, it is unlikely that the inorganic parameters of the water have a significant effect on the extractability of the organic compounds.

Duplicate experiments were performed under each experimental condition (Table 2) for quality assurance. Samples were held at maximum temperature for the entire duration of the experiments. After the aqueous extraction period was completed, the water from the coal extraction was filtered (while still hot, for hot water bath and Soxhlet runs) using clean (baked at $450{ }^{\circ} \mathrm{C}$ ) Whatman GF/C glass microfiber filters $(1 \mu \mathrm{m}$ pore size). Pesticide grade dichloromethane $(30 \mathrm{ml})$ was added to the filtered water extract for stabilization. Samples were liquid-liquid extracted with 3 sequential volumes of $30 \mathrm{ml}$ pesticide grade dichloromethane to isolate the organic compounds in the filtered aqueous extract. The combined extract $(120 \mathrm{ml})$ was concentrated by rotoevaporation, followed by evaporation under nitrogen. Samples were brought up in 50-2,000 $\mu$ l pesticide grade dichloromethane, and 1-2 $\mu \mathrm{l}$ each was used for analysis by gas chromatography (GC), and gas chromatography/mass spectrometry (GC/MS).

Analytical methods

Samples were analyzed using a Perkin Elmer (Boston, MA, USA) 8500 GC with a Flame Ionization Detector (FID) and a Hewlett Packard (Agilent Technologies, Palo Alto, CA, USA) 6890 Series GC System with a 5973 Mass Selective Detector equipped with an Agilent 7683 Series Injector. Samples were first analyzed by GC-FID in order to determine whether separation by liquid chromatography (LC) was needed prior to GC/MS analysis. A $30 \mathrm{~m} \times 250 \mu \mathrm{m} \times 0.25 \mu \mathrm{m}$ J\&W DB-5 column (95\% dimethyl, $5 \%$ diphenyl polysiloxane) was used for GC-FID analysis using the following conditions: $1.0 \mu \mathrm{l}$ splitless injection; injector temperature of $150{ }^{\circ} \mathrm{C}$; detector temperature of $325^{\circ} \mathrm{C}$; temperature program of $70-325{ }^{\circ} \mathrm{C}$ at $4{ }^{\circ} \mathrm{C} / \mathrm{min}$ with a final hold at $325^{\circ} \mathrm{C}$ for $20 \mathrm{~min}$; and 13 psig column pressure. LC columns were packed with silicic acid (BIOSIL A, 100-200 mesh) and aluminum oxide (Neutral Alumina AG7, 100-200 mesh).

GC/MS was used for structural identification and quantification of the organic compounds. A $30 \mathrm{~m} \times 250 \mu \mathrm{m} \times 0.25 \mu \mathrm{m}$ HP-5MS column $(95 \%$ dimethyl, $5 \%$ diphenyl polysiloxane) was used for GC/MS analysis, with the following conditions: 1-2 $\mu$ l splitless injection; a constant flow of $1.0 \mathrm{ml} /$ min; solvent delay of $6.0 \mathrm{~min}$; injector temperature of $150{ }^{\circ} \mathrm{C}$; interface at $300{ }^{\circ} \mathrm{C}$; temperature program of $70-300{ }^{\circ} \mathrm{C}$ at $4{ }^{\circ} \mathrm{C} / \mathrm{min}$ with a final hold at $300{ }^{\circ} \mathrm{C}$ for $15 \mathrm{~min}$; and a mass scan from 50 to $550 \mathrm{Da}$ (Dalton).

Laboratory, GC, and GC/MS blanks were used for quality assurance. Laboratory blanks consisted of 
milliQ water extracted with pesticide grade dichloromethane, subjected to the same processing conditions as samples. GC and GC/MS blanks were run prior to each analysis. Organic compounds in samples were identified by comparison of mass spectral features to reference libraries of mass spectral data [National Institute of Standards and Technology (NIST98) and Wiley 7] included in the GC/MS system, and interpreted visually, or by comparison to standard compounds. Compounds identified at a match quality of $\geq 90 \%$ against the mass spectral databases are reliably identified. Match qualities between 89 and $50 \%$ may be considered tentatively identified, and those $<50 \%$ should be considered unreliable, and the compound should be considered unknown or unidentified. Average ion composition was calculated for each peak, and peak deconvolution was performed on all peaks.

External aliphatic and aromatic standards, injected under the same conditions as samples, were used for quantification. Due to the impracticality of preparing standards with hundreds of compounds, aliphatic standards consisted of 32 compounds (C8 through C40) at 1 and $4 \mathrm{ppm}$ concentration, and aromatic standards consisted of 23 major compounds, prepared in part from EPA 610 (and contained, for example, acenaphthene, acenaphthylene, anthracene, benz(a)anthracene, benzo(a)pyrene, benzo(b)fluoranthene, benzo(g,h,i)perylene, benzo(k)fluoranthene, chrysene, dibenz(a,h)anthracene, fluoranthene, fluorene, indeno(1,2,3-cd)pyrene, naphthalene, phenanthrene, pyrene) at 1 and $10 \mathrm{ppm}$ concentration. To quantitate compounds in samples, a subset of 3 standard compounds with known retention times were chosen for each sample. Compounds in samples were quantified using standards with retention times that best corresponded to the retention time ranges (i.e., $\leq 25$, $26-44$, and $\geq 45 \mathrm{~min}$ ) of the sample compounds. As the majority of sample compounds were not quantified with the actual standard for that compound, the majority of sample compound concentration results are semi-quantitative. Inferential statistics were not employed because group sizes were too small for results, whether they would have shown statistical significant or no statistical significance, to have been meaningful.

\section{Results}

Laboratory blank concentrations of organic compounds were very low, and show that contamination associated with laboratory methods, for example, extraction and rotoevaporation, was negligible. All GC and GC/MS blank runs showed no peaks discernable above background, indicating no sample or standard carryover.

Table 3 lists the total number of organic compounds present in samples [at abundances proportional to $\geq 25,000$ counts $(\sim 0.01 \mathrm{ng} / \mu \mathrm{l})$ for a $1 / 50-\mu \mathrm{l}$ injection], and percentages of organic compounds identified at match qualities of $\geq 90,89-50$, and $<50 \%$. Some compounds listed as a match quality of $89-50 \%$ may have been a $\geq 90 \%$ match quality, as the GC/MS scans began at $50 \mathrm{~m} / \mathrm{z}$ (atomic mass to charge ratio). Tables 4 and 5 list the percentages and concentrations, respectively, of aliphatic and aromatic compound groups with a match quality of $\geq 90 \%$. Experiments in Tables 2, 3, 4, 5 are grouped by run conditions, and within each experimental subgroup by sample origin, that is, nonendemic followed by endemic area coals.

Duplicate aqueous extraction experiments show consistency in aliphatic and aromatic compound concentrations (Table 5). Room temperature aqueous extraction experiments using endemic area Pliocene lignite samples produced many more organic compounds and in greater concentrations than bituminous coals run under identical conditions (Fig. 2). Room temperature experiments using an endemic area Pliocene lignite sample also produced many more organic compounds and in greater concentrations than nonendemic area lignites from Romania and the USA run under identical conditions (Fig. 3).

Similar results were obtained for hot water bath experiments. Aqueous extracts of endemic area Pliocene lignites contained more organic compounds and in higher concentrations than nonendemic area samples (Fig. 4). Hot water bath experiments yielded a higher concentration of saturated aliphatic compounds, phthalate esters, phenols, benzenes, heterocycles, and lignin degradation compounds than room temperature experiments (Table 5). Aqueous Soxhlet extraction experiments produced much more complex GC/MS chromatograms than either room temperature or hot water bath extraction experiments, and also showed more and higher concentrations of organic compounds extracted from endemic area Pliocene lignites compared to all other coals (Fig. 5). Soxhlet experiments also yielded a higher concentration of functional derivative aliphatics, hydroxy-, methoxy-phenols, 
Table 3 Number and percentages of organic compounds in samples

\begin{tabular}{|c|c|c|c|c|c|}
\hline Sample \# & Region and rank & $\begin{array}{l}\text { No. of } \\
\text { compounds } \\
\text { present }\end{array}$ & $\begin{array}{l}\text { Percentage } \\
\text { identified } \\
\text { match } \geq 90 \%\end{array}$ & $\begin{array}{l}\text { Percentage } \\
\text { identified } \\
\text { match 89-50\% }\end{array}$ & $\begin{array}{l}\text { Percentage } \\
\text { identified } \\
\text { match }<50 \%\end{array}$ \\
\hline Rt-A-1 & Nonendemic bituminous & 29 & 41 & 24 & 35 \\
\hline Rt-A-2 & Nonendemic bituminous & 11 & 46 & 27 & 27 \\
\hline Rt-A-4 & Endemic lignite & 47 & 23 & 53 & 23 \\
\hline Rt-C-4 & Nonendemic bituminous & 5 & 80 & 0 & 20 \\
\hline Rt-C-5 & Nonendemic lignite & 28 & 46 & 39 & 14 \\
\hline Rt-C-2 & Nonendemic lignite & 9 & 56 & 33 & 11 \\
\hline Rt-C-3 & Nonendemic lignite & 12 & 17 & 50 & 33 \\
\hline Rt-C-1 & Endemic lignite & 31 & 16 & 45 & 39 \\
\hline Rt-B-1 & Nonendemic bituminous & 6 & 50 & 50 & 0 \\
\hline Rt-B-2 & Nonendemic bituminous & 5 & 40 & 40 & 20 \\
\hline Rt-B-3 & Endemic lignite & 34 & 12 & 44 & 44 \\
\hline Rt-B-4 & Endemic lignite & 19 & 16 & 53 & 32 \\
\hline Hb-A-1 & Nonendemic bituminous & 84 & 43 & 36 & 21 \\
\hline Hb-A-2 & Nonendemic bituminous & 76 & 32 & 32 & 37 \\
\hline Hb-A-6 & Nonendemic bituminous & 38 & 58 & 32 & 11 \\
\hline Hb-A-5 & Nonendemic lignite & 28 & 32 & 36 & 32 \\
\hline $\mathrm{Hb}-\mathrm{A}-3$ & Endemic lignite & 117 & 19 & 42 & 39 \\
\hline $\mathrm{Hb}-\mathrm{A}-8$ & Endemic lignite & 172 & 19 & 32 & 49 \\
\hline Sx-F-1 & Nonendemic bituminous & 95 & 13 & 47 & 40 \\
\hline Sx-F-2 & Nonendemic bituminous & 102 & 15 & 42 & 43 \\
\hline Sx-F-7 & Nonendemic bituminous & 112 & 21 & 46 & 33 \\
\hline Sx-F-8 & Nonendemic lignite & 392 & 5 & 17 & 78 \\
\hline Sx-F-6 & Nonendemic lignite & 193 & 8 & 35 & 57 \\
\hline Sx-F-5 & Endemic lignite & $278^{\mathrm{a}}$ & 6 & 34 & 60 \\
\hline Sx-F-3 & Endemic lignite & $352^{\mathrm{a}}$ & 7 & 18 & 75 \\
\hline Sx-F-4 & Endemic lignite & $301^{\mathrm{a}}$ & 6 & 23 & 71 \\
\hline
\end{tabular}

$R t$ room temperature, $H b$ hot water bath, $S x$ Soxhlet

a Contains 200-400 more compounds

PAHs, hydroxy-, methoxy-benzenes, and lignin degradation compounds than room temperature or hot water bath experiments (Table 5).

Pebble-sized Husnicioara samples run under higher temperature experimental conditions (i.e., $75^{\circ}$ and $80{ }^{\circ} \mathrm{C}$ ) produced a higher concentration of aromatic compounds than corresponding finer grained $(<297 \mu \mathrm{m})$ Husnicioara samples, particularly for the lignin degradation subgroup.

Many samples contained phthalate esters, ubiquitous environmental contaminants of anthropogenic origin. As laboratory blank concentrations of organic compounds were very low, the phthalate esters represent contamination of the coal prior to processing in the laboratory.

\section{Discussion}

Greater numbers and higher concentrations of organic compounds were present in aqueous leachates of endemic area Pliocene lignites compared to the other coals examined. Though some organic compound information from extracts of bituminous coals have been presented before (Zhao et al. 2000; Tatu et al. 2000a, b; 2003; Orem et al. 2002; Feder et al. 2002), and we expected these higher ranking coals to have lower numbers and concentrations of organic compounds than lignites, components extracted from coal vary depending on, for example, the solvent, temperature, and time used; therefore, their inclusion in this study was necessary in order to directly compare coal 


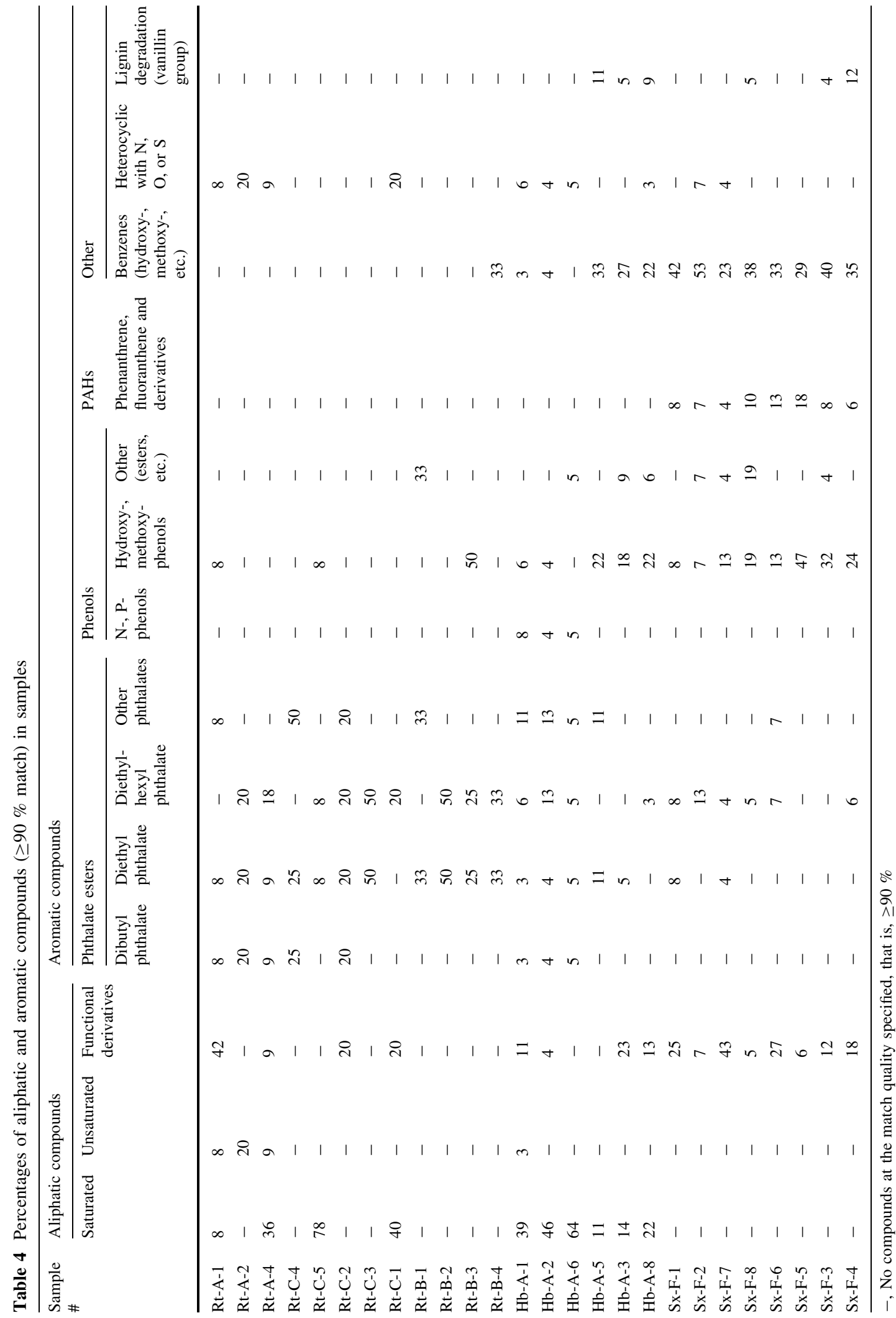




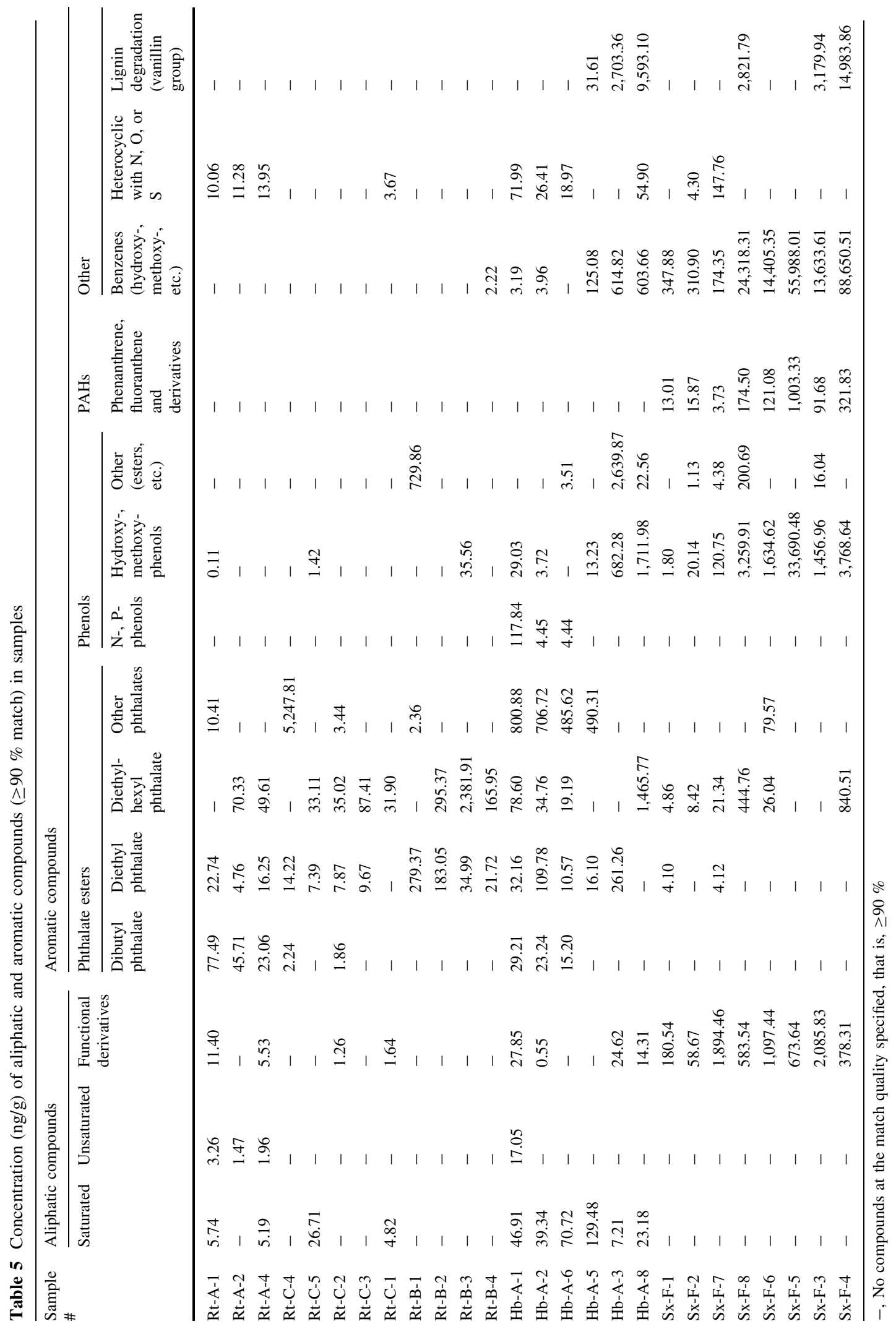




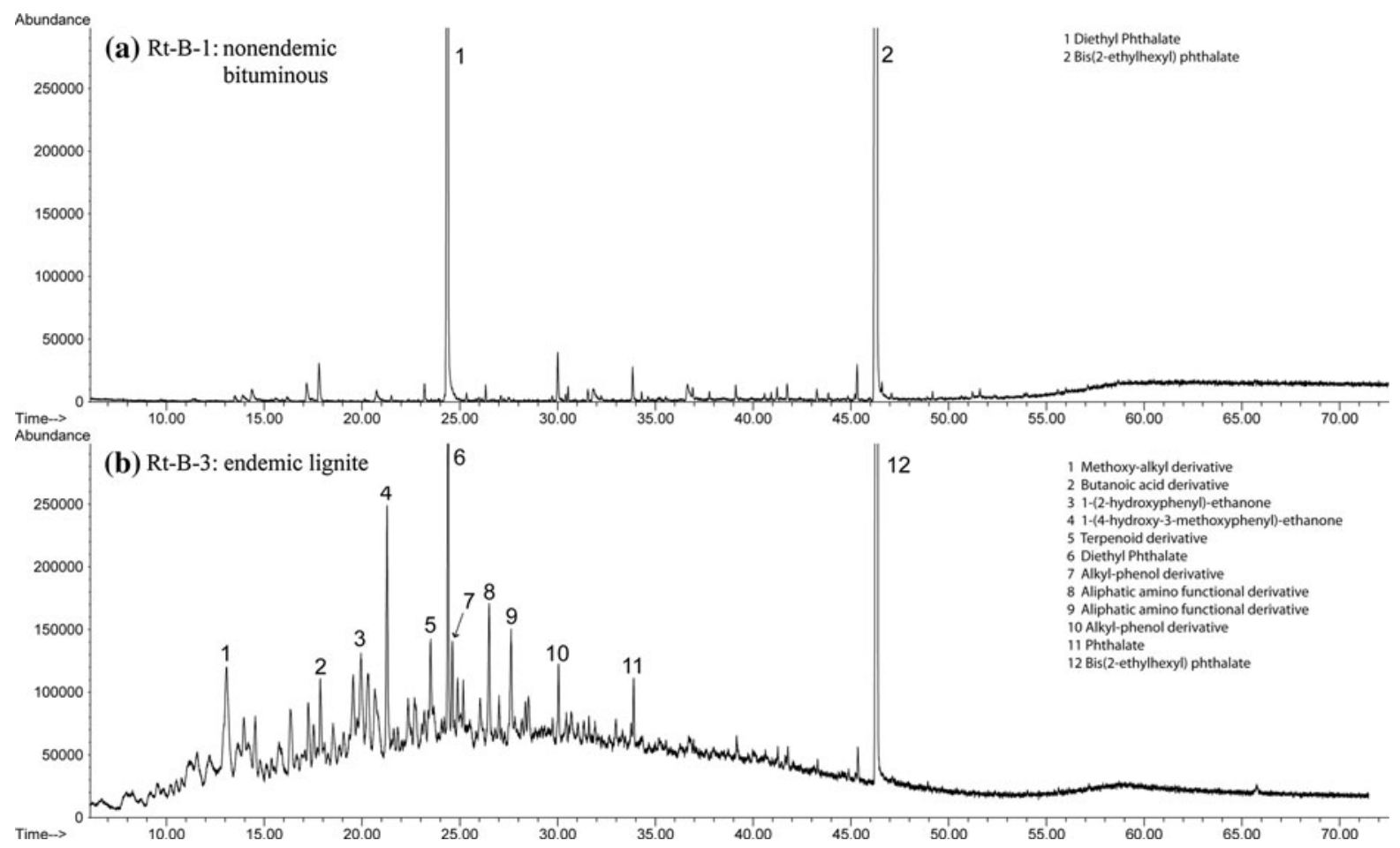

Fig. 2 GC-MS chromatographs of room temperature experiments held at $25{ }^{\circ} \mathrm{C}$ for 128 days comparing bituminous coal and endemic area lignite samples. a Rt-B-1, a bituminous coal (i.e., IRC \#36), and b Rt-B-3, an endemic area lignite sample (i.e., Husnicioara) showing more organic compounds and in higher concentrations than in $\mathbf{a}$ sample extract yields under the experimental conditions used.

Results of leaching experiments using lignite samples may be influenced by different grain sizes because of differences in surface area (Izquierdo et al. 2011). The higher concentration of aromatic compounds in the higher temperature (i.e., $75^{\circ}$ and $80{ }^{\circ} \mathrm{C}$ ) pebble-sized Husnicioara sample experiments versus corresponding finer grained $(<297 \mu \mathrm{m})$ sample experiments suggest leaching from coal sample surface exteriors, as the coarser grained samples possessed higher ratios of total exposed exterior surface area:interior grain surface area.

Similar concentrations of saturated and unsaturated aliphatic compounds and their functional derivatives were found in aqueous leachates of endemic area Pliocene lignites and the other coals examined, suggesting that these compounds do not play an etiological role in BEN. Many aromatic compounds, for example, PAHs and aromatic amines, are known or suspected carcinogens, or have been linked to urinary tract cancer and tubulointerstitial nephropathies (Tatu et al. 1998). A BEN causative agent or agents may be among the numerous aromatic compound classes identified in the extracts (phenols, PAHs, benzenes), as for example, in the experiments designed to gauge exposure to groundwater leaching of organic compounds over long periods of time (i.e., hot water bath and Soxhlet), hydroxy-, methoxy-phenols and hydroxy-, methoxy-benzenes occur in much higher concentrations in extracts of endemic area Pliocene lignites compared to the other coals and conditions examined.

As the majority of samples contain $\geq 50 \%$ of their compounds identified with match qualities of 89-50 or $<50 \%$, a specific BEN causative molecule or molecules may also be among these compounds, or among the hundreds of compounds present in lower concentrations than addressed in this study. The relatively low concentrations of compounds (in the ng to $\mu \mathrm{g} / \mathrm{g}$ range) present in samples, however, may provide a plausible explanation for the extended time required 

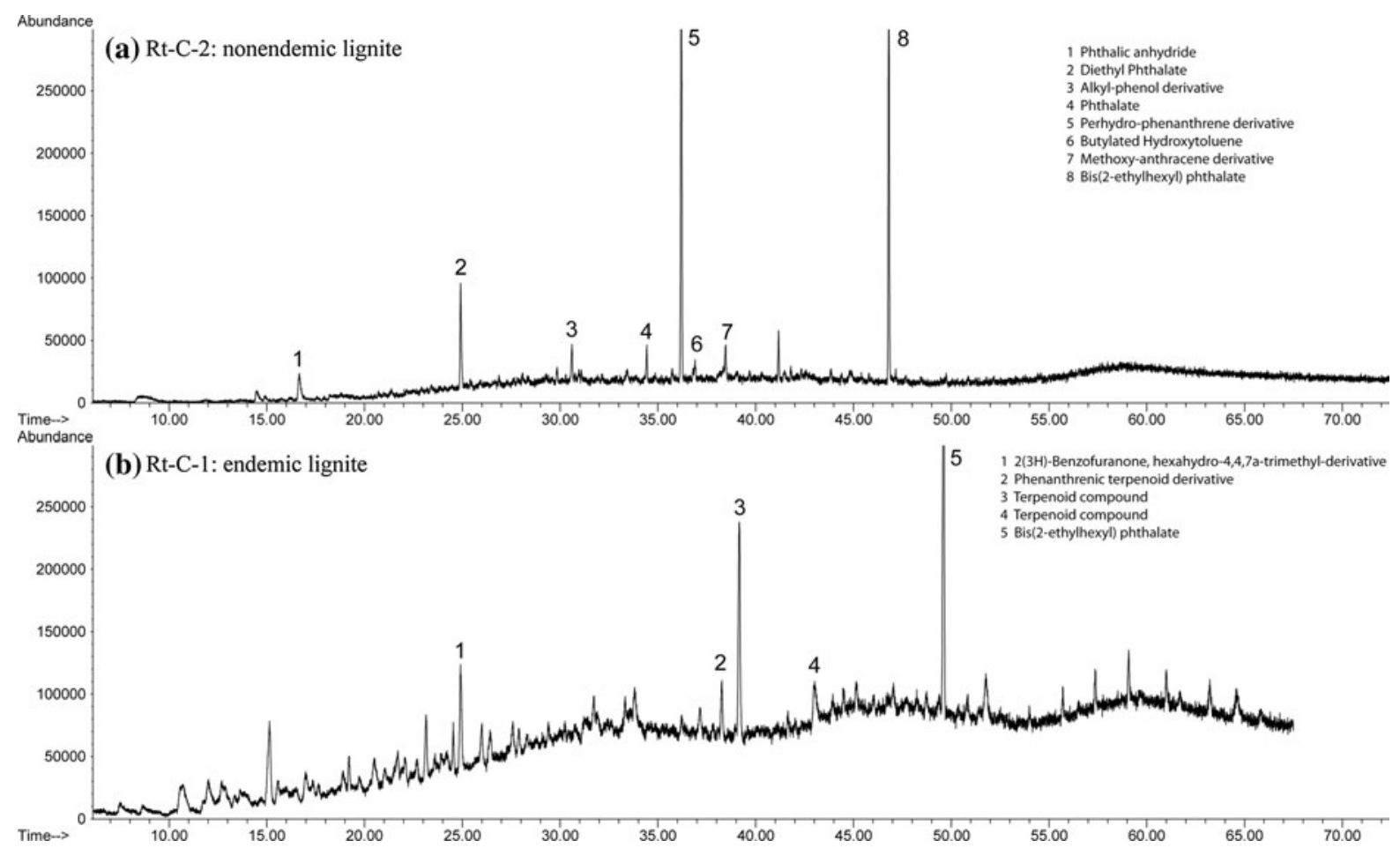

Fig. 3 GC-MS chromatographs of room temperature experiments held at $25^{\circ} \mathrm{C}$ for 97 days comparing nonendemic and endemic area lignite samples. a Rt-C-2, a nonendemic area

for kidney failure and upper urinary tract cancer to develop in BEN patients.

Many organic compounds in endemic area Pliocene lignite coal extracts were also found in water supply samples (Orem et al. 2004) of endemic (but not nonendemic) regions in Romania, including cycloalkanes/alkenes, steranic structures, monoaromatic and polyaromatic terpanes, polycyclic aromatic hydrocarbons, and aromatic amines, suggesting a connection and link to the source of the compounds found in the water. In addition, phenolic compounds and aromatic derivatives present in the water supply samples were attributed to either anthropogenic pollution or a geologic source (Orem et al. 2004). However, the higher concentrations of hydroxy-, methoxy-phenols, PAHs and derivatives, and hydroxy-, methoxy-benzenes present in the higher temperature extracts of endemic area Pliocene lignites (compared to extracts of other coals), show that the organics detected in the endemic water supply samples are more consistent with a geologic source, that is, Pliocene lignites. lignite sample (i.e., Brad), and b Rt-C-1, an endemic area lignite sample (i.e., Bpesyn) showing more organic compounds and in higher concentrations than in a

Thus, this study shows that many aromatic compounds present in endemic area Pliocene lignite coals are water-soluble (at least in part, as particles are $\leq 1 \mu \mathrm{m}$ ), water-leachable, and water-extractable. The proposed exposure pathway of the Pliocene lignite hypothesis (i.e., organic compounds in endemic area Pliocene lignites $\rightarrow$ leached by groundwater $\rightarrow$ organic compounds in well and spring drinking water) is therefore likely, and indicates (with the presented results) that the source of some of the organic compounds in endemic area water supply samples is the proximal Pliocene lignite coal deposits.

However, exposure to organic compounds leached from Pliocene lignite coal deposits into well and spring drinking water in endemic BEN areas alone cannot explain the etiology of the disease, as for example, not all individuals residing in endemic villages develop BEN. Genetic susceptibility is also involved in the emergence of the disease. For example, the gene-environment interaction is translated into unusual xenobiotic substance metabolism (controlled 


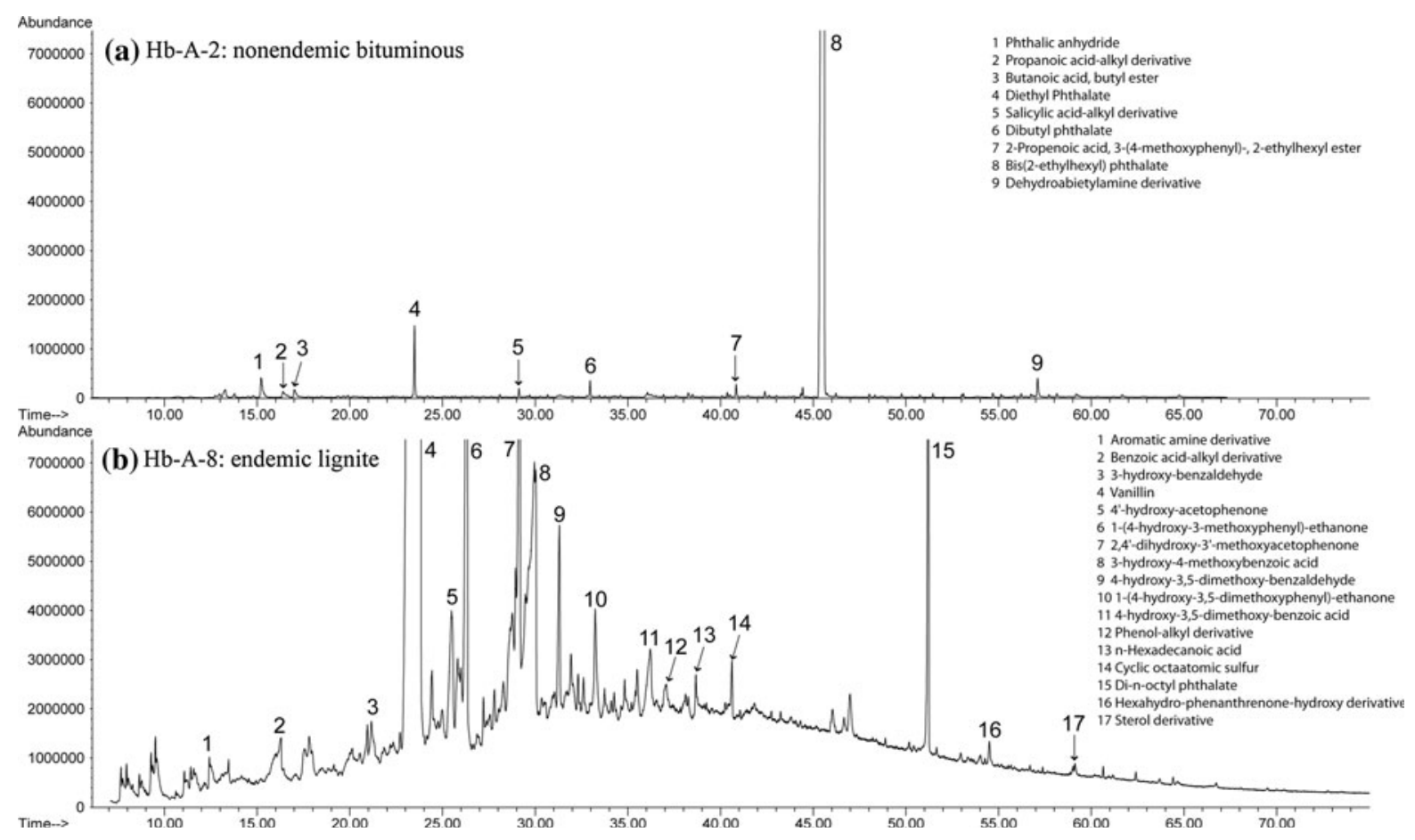

Fig. 4 GC-MS chromatographs of hot water bath experiments held at $75{ }^{\circ} \mathrm{C}$ for 5 days comparing bituminous coal and endemic area lignite samples. a Hb-A-2, a bituminous coal (i.e.,
IRC \#36), and b Hb-A-8, an endemic area lignite sample (i.e., Husnicioara pebbles) showing more organic compounds and in higher concentrations than in a by cytochrome $P 450$ and other enzymes) that increases the risk to develop BEN only in those individuals that bear certain gene variants that code for the detoxification enzymes (Atanasova et al. 2005).

Future work

Additional research on this subject is warranted for an improved understanding of the role of the Pliocene lignite hypothesis in the etiology of BEN. Additional work should address the identification and concentration of compounds with match qualities of $89-50 \%$, and of compounds with lower concentrations than investigated here. Also, a compound-by-compound assessment for known or suspected causal links to tubulointerstitial nephropathies and urinary tract cancers appear needed, as well as a compound-bycompound comparison of endemic and nonendemic area extract yields from this study to those of water supply samples. Future experiments should be conducted on a greater number of samples, using longer time durations, and with water that better mimics the natural inorganic groundwater composition. Coal samples for future experiments should include Pliocene lignites from neighboring countries with no known cases of BEN, for example, Greece, Slovenia, and Turkey, in order to further narrow the comparison of coals to similar rank and flora.

\section{Conclusions}

This study supports the role of the Pliocene lignite hypothesis as a factor in the etiology of Balkan endemic nephropathy. Water-soluble, water-leachable, and water-extractable aromatic compounds with functional groups with potential toxicity have been demonstrated to be leached from endemic area Pliocene lignite coal samples under a number of experimental conditions. A BEN causing molecule or molecules may be among phenols, PAHs, benzenes, and/or lignin degradation compounds, as these compounds occurred in greater concentrations in extracts of endemic area Pliocene lignite sample experiments that best mimicked longterm compound exposure, compared to all other coals and conditions examined. In addition, some of these 


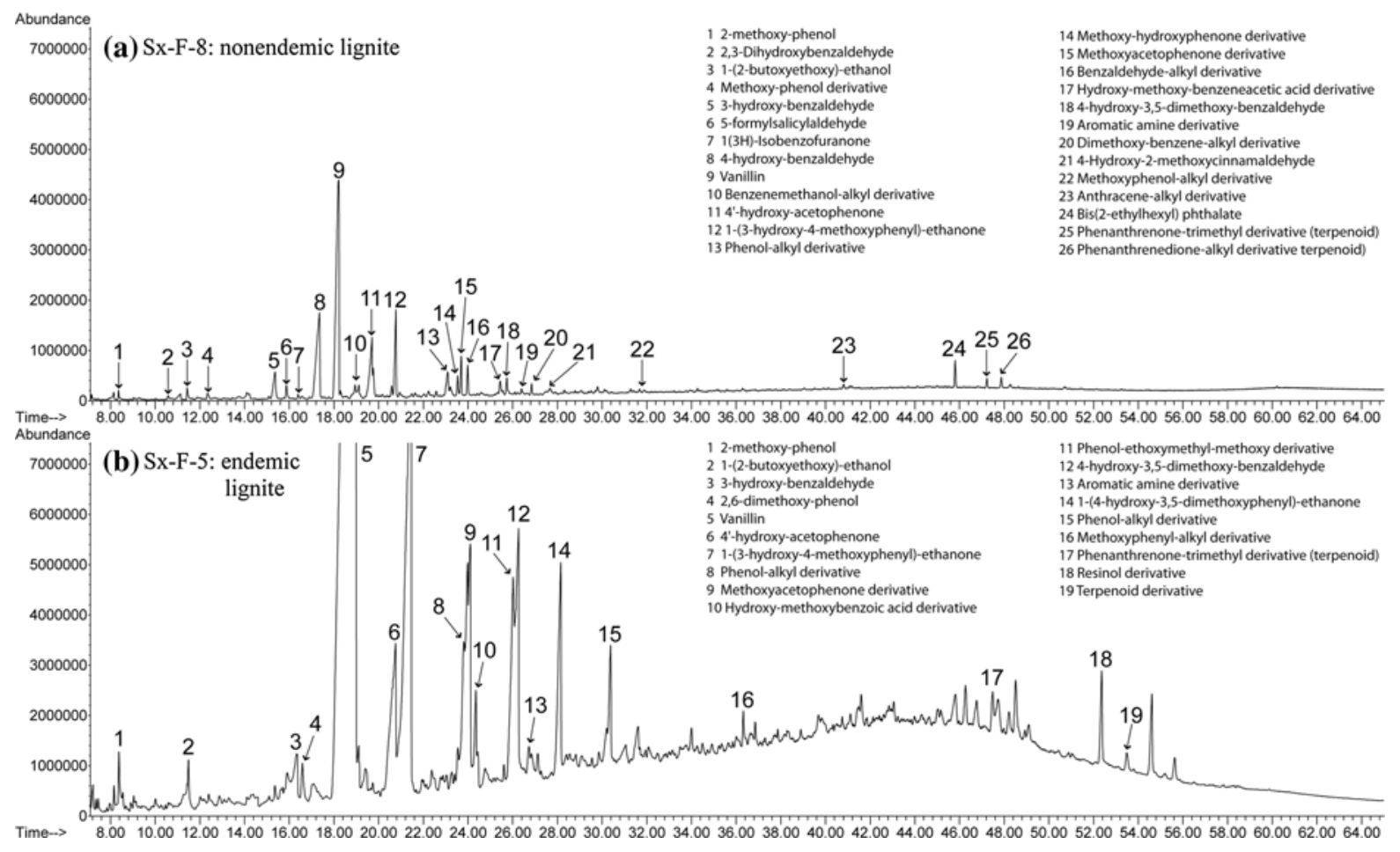

Fig. 5 GC-MS chromatographs of Soxhlet experiments held at $80{ }^{\circ} \mathrm{C}$ for 5 days comparing nonendemic and endemic area lignite samples. a Sx-F-8, a nonendemic area lignite sample

same compounds have been identified in endemic (but not nonendemic) area water supply samples, and therefore, indicate a link to the proximal Pliocene lignite coal deposits. The concentrations of organic compounds are low, in the $\mathrm{ng}$ to $\mu \mathrm{g} / \mathrm{g}$ range, and may account for the long time required for development of the disease. The proposed transport pathway of the Pliocene lignite hypothesis for organic compound exposure from endemic Pliocene lignite coals to well and spring drinking water, is therefore, likely.

Acknowledgments Support for this work was provided through a grant from the US Geological Survey and NATO collaborative linkage grants (EST.CLG.975818 and EST.CLG.977806) to W.H. Orem, and a US Geological Survey assistance award grant (00HQAG0213) and funding from the Romanian Ministry of Health to C.A. Tatu. We thank Curtis Palmer and Mathew Varonka (USGS, Reston, VA, USA) for sample IRC \#36, and help with chromatogram labeling, respectively. Drs. Harvey Belkin and Allan Kolker (USGS internal reviewers), and two anonymous journal reviewers provided constructive comments that led to an improved manuscript, and are gratefully acknowledged for their scientific and medical expertise and time. Any use of trade, (i.e., Haegel), and b Sx-F-5, an endemic area lignite sample (i.e., Bpesyn) showing more organic compounds and in higher concentrations than in a

product, or firm names is for descriptive purposes only and does not imply endorsement by the US Government.

Open Access This article is distributed under the terms of the Creative Commons Attribution License which permits any use, distribution, and reproduction in any medium, provided the original author(s) and the source are credited.

\section{References}

Apostolov, K., Spasic, P., \& Bojanic, N. (1975). Evidence of a viral etiology in endemic (Balkan) nephropathy. Lancet, $11,1271$.

Arlt, V. M., Stiborova, M., vom Brocke, J., Simoes, M. L., Lord, G. M., Nortier, J. L., et al. (2007). Aristolochic acid mutagenesis: Molecular clues to the aetiology of Balkan endemic nephropathy-associated urothelial cancer. Carcinogenesis, 28, 2253-2261.

Atanasova, S. Y., von Ahsen, N., Toncheva, D. I., Dimitrov, T. G., Oellerich, M., \& Armstrong, V. W. (2005). Genetic polymorphisms of cytochrome P450 among patients with Balkan endemic nephropathy (BEN). Clinical Biochemistry, 38, 223-228. 
Baba, A., \& Kaya, A. (2004). Leaching characteristics of solid wastes from thermal power plants of western Turkey and comparison of toxicity methodologies. Journal of Environmental Management, 73, 199-207.

Bales, R. C., Li, S., Jim Yeh, T.-C., Lenczewski, M. E., \& Gerba, C. P. (1997). Bacteriophage and microsphere transport in saturated porous media: Forced-gradient experiment at Borden, Ontario. Water Resources Research, 33, 639-648.

Barbir, F., \& Veziroglu, T. N. (1992). Assessment of environmental damage by fossil fuels. In Y. Yurum (Ed.), Clean utilization of coal (pp. 131-152). The Netherlands: Kluwer Academic Publishers.

Batuman, V. (1991). Possible pathogenetic role of low-molecular-weight proteins in Balkan nephropathy. Kidney International, 40(Suppl 34), S89-S92.

Bechtel, A., Sachsenhofer, R. F., Markic, M., Gratzer, R., Lucke, A., \& Puttmann, W. (2003). Paleoenvironmental implications from biomarker and stable isotope investigations on the Pliocene Velenje lignite seam (Slovenia). Organic Geochemistry, 34, 1277-1298.

Bozic, Z., Duancic, V., Belicza, M., Kraus, O., \& Skljarov, I. (1995). Balkan endemic nephropathy: Still a mysterious disease. European Journal of Epidemiology, 11, 235-238.

Bunnell, J. E., Tatu, C. A., Bushon, R. N., Stoeckel, D. M., Brady, A. M. G., Beck, M., et al. (2006). Possible linkages between lignite aquifers, pathogenic microbes, and renal pelvic cancer in northwestern Louisiana, USA. Environmental Geochemistry and Health, 28, 577-587.

Bunnell, J. E., Tatu, C. A., Lerch, H. E., Orem, W. H., \& Pavlovic, N. (2007). Evaluating nephrotoxicity of highmolecular-weight organic compounds in drinking water from lignite aquifers. Journal of Toxicology and Environmental Health, Part A, 70, 2089-2091.

Ceovic, S., Hrabar, A., \& Saric, M. (1992). Epidemiology of Balkan endemic nephropathy. Food and Chemical Toxicology, 30, 183-188.

Chakraborty, R., \& Mukherjee, A. (2009). Mutagenicity and genotoxicity of coal fly ash water leachate. Ecotoxicology and Environmental Safety, 72, 838-842.

Christensen, J. B., \& Christensen, T. H. (1999). Complexation of $\mathrm{Cd}, \mathrm{Ni}$, and $\mathrm{Zn}$ by DOC in polluted groundwater: A comparison of approaches using resin exchange, aquifer material sorption, and computer speciation models (WHAM and MINTEQA2). Environmental Science and Technology, 33, 3857-3863.

Craciun, E., \& Rosculescu, I. (1970). On Danubian endemic familial nephropathy (Balkan nephropathy). The American Journal of Medicine, 49, 774-779.

Cukuranovic, R., Ignjatovic, M., \& Stefanovic, V. (1991). Urinary tract tumors and Balkan nephropathy in the South Morava River basin. Kidney International, 40(34), S80S84.

Danilovic, V., Djurisic, M., Mokranjac, M., Stojimirovic, B., Zivojinovic, J., \& Stojakovic, P. (1957). Chronic nephritis caused by poisoning with lead via the digestive tract (flour). Presse Medicale, 65, 2039-2040.

Feder, G. L., Radovanovic, Z., \& Finkelman, R. B. (1991). Relationship between weathered coal deposits and the etiology of Balkan endemic nephropathy. Kidney International, 40(34), S9-S11.
Feder, G. L., Tatu, C. A., Orem, W. H., Paunescu, V., Dumitrascu, V., Szilagyi, D. N., et al. (2002). Weathered coal deposits and Balkan endemic nephropathy. Facta Universitatis, 9, 34-38.

Finkelman, R. B. (2007). Health impacts of coal: Facts and fallacies. Ambio, 36, 103-106.

Finkelman, R. B., Belkin, H. E., \& Zheng, B. (1999). Health impacts of domestic coal use in China. Proceedings of the National Academy of Sciences, 96, 3427-3431.

Finkelman, R. B., Centeno, J. A., \& Selinus, O. (2005). The emerging medical and geological association. Transactions of the American Clinical and Climatological Association, 116, 155-165.

Finkelman, R. B., \& Gross, P. M. K. (1999). The types of data needed for assessing the environmental and human health impacts of coal. International Journal of Coal Geology, 40, 91-101.

Finkelman, R. B., Orem, W., Castranova, V., Tatu, C. A., Belkin, H. E., Zheng, B., et al. (2002). Health impacts of coal and coal use: Possible solutions. International Journal of Coal Geology, 50, 425-443.

Gaitan, E., Cooksey, R. C., Legan, J., Cruse, J. M., Lindsay, R. H., \& Hill, J. (1993). Antithyroid and goitrogenic effects of coal-water extracts from iodine-sufficient goiter areas. Thyroid, 3, 49-53.

Gaon, J., Griggs, R. C., Vasiljevic, M., \& Alibegovic, S. (1962). Investigation of endemic nephropathy in Yugoslavia: I. Lead as a possible etiologic agent. Acta Medica Yugoslavica, 16, 346-352.

Georgescu, L., Litvac, B., Diosi, P., Plavosin, I., \& Herzog, G. (1976). Viruses in endemic (Balkan) nephropathy. Lancet, $15,1086$.

Gluhovschi, G., Margineanu, F., Velciov, S., Gluhovschi, C., Bob, F., Petrica, L., et al. (2011a). Fifty years of Balkan endemic nephropathy in Romania: Some aspects of the endemic focus in the Mehedinti county. Clinical Nephrology, 75, 34-48.

Gluhovschi, G. H., Modalca, M., Margineanu, F., Velciov, S., Gluhovschi, C., Bob, F., et al. (2011b). Epidemiological data regarding Balkan endemic nephropathy in relationship with the Pliocene coal etiological hypothesis. Romanian Journal of Internal Medicine, 49, 11-24.

Goldberg, M. C., Feder, G. L., \& Radovanovic, Z. (1994). Correlation of Balkan endemic nephropathy with fluorescent organic compounds in shallow ground water. Applied Hydrogeology, 2, 15-23.

Grollman, A. P., \& Jelakovic, B. (2007). Role of environmental toxins in endemic (Balkan) nephropathy. Journal of the American Society of Nephrology, 18, 2817-2823.

Hranjec, T., Kovac, A., Kos, J., Mao, W., Chen, J. J., Grollman, A. P., et al. (2005). Endemic nephropathy: The case for chronic poisoning by Aristolochia. Croatian Medical Journal, 46, 116-125.

Iordanidis, A., \& Georgakopoulos, A. (2003). Pliocene lignites from Apofysis mine, Amynteo basin, Northwestern Greece: Petrographical characteristics and depositional environment. International Journal of Coal Geology, 54, 57-68.

Ivic, M. (1970). The problem of aetiology of endemic nephropathy. Acta Facultatis medicae Naissensis, 1, 29-38. 
Izquierdo, M., Koukouzas, N., Touliou, S., Panopoulos, K. D., Querol, X., \& Itskos, G. (2011). Geochemical controls on leaching of lignite-fired combustion by-products from Greece. Applied Geochemistry, 26, 1599-1606.

Jung, H. B., Charette, M. A., \& Zheng, Y. (2009). A field, laboratory and modeling study of reactive transport of groundwater arsenic in a coastal aquifer. Environmental Science and Technology, 43, 5333-5338.

Kavouridis, K., \& Koukouzas, N. (2008). Coal and sustainable energy supply challenges and barriers. Energy Policy, 36, 693-703.

Koopmans, M. P., Schaeffer-Reiss, C., De Leeuw, J. W., Lewan, M. D., Maxwell, J. R., Schaeffer, P., et al. (1997). Sulphur and oxygen sequestration of $n-\mathrm{C}_{37}$ and $n-\mathrm{C}_{38}$ unsaturated ketones in an immature kerogen and the release of their carbon skeletons during early stages of thermal maturation. Geochimica et Cosmochimica Acta, 61, 2397-2408.

Koukouzas, N., Vasilatos, C., Itskos, G., Mitsis, I., \& Moutsatsou, A. (2010). Removal of heavy metals from wastewater using CFB-coal fly ash zeolitic materials. Journal of Hazardous Materials, 173, 581-588.

Koukouzas, N., Ward, C. R., Papanikolaou, D., Li, Z., \& Ketikidis, C. (2009). Quantitative evaluation of minerals in fly ashes of biomass, coal and biomass-coal mixture derived from circulating fluidized bed combustion technology. Journal of Hazardous Materials, 169, 100-107.

Kruger, O., Kalbe, U., Berger, W., Simon, F.-G., \& Lopez Meza, S. (2012). Leaching experiments on the release of heavy metals and PAH from soil and waste materials. Journal of Hazardous Materials, 207-208, 51-55.

Long, D. T., \& Voice, T. C. (2007). Role of exposure analysis in solving the mystery of Balkan endemic nephropathy. Croatian Medical Journal, 48, 300-311.

Maharaj, S. V. M. (2013) Role of the Pliocene lignite hypothesis in the etiology of Balkan endemic nephropathy: Limitations and plausibility. International Journal of Occupational and Environmental Health, manuscript in preparation.

Maksimovic, Z. (1991). Selenium deficiency and Balkan endemic nephropathy. Kidney International, 40(34), S12S14.

Mastrangelo, G., Fadda, E., \& Marzia, V. (1996). Polycyclic aromatic hydrocarbons and cancer in man. Environmental Health Perspectives, 104, 1166-1170.

McElmurry, S. P., \& Voice, T. C. (2004). Screening methodology for coal-derived organic contaminants in water. International Journal of Environmental Analytical Chemistry, 84, 277-287.

Mihailovic, M., Lindberg, P., Jovanovic, I., \& Antic, D. (1992). Selenium status of patients with Balkan endemic nephropathy. Biological Trace Element Research, 33, 71-77.

Morozov, V. N., Morozova, T. Y., Bray, P., Hranisavljevic, J., \& Vucelic, D. (1991). Survey of small molecule and ion binding to $\beta_{2}$-microglobulin-Possible relation to BEN. Kidney International, 40(34), S85-S88.

Mumford, J. L., He, X. Z., Chapman, R. S., Cao, S. R., Harris, D. B., Li, X. M., et al. (1987). Lung cancer and indoor air pollution in Xuan Wei, China. Science, 235, 217-220.

Mumford, J. L., Li, X., Hu, F., Lu, X. B., \& Chuang, J. C. (1995). Human exposure and dosimetry of polycyclic aromatic hydrocarbons in urine from Xuan Wei, China with high lung cancer mortality associated with exposure to unvented coal smoke. Carcinogenesis, 16, 3031-3036.

Niagolova, N., McElmurry, S. P., Voice, T. C., Long, D. T., Petropoulos, E. A., Havezov, I., et al. (2005). Nitrogen species in drinking water indicate potential exposure pathway for Balkan Endemic Nephropathy. Environmental Pollution, 134, 229-237.

Orem, W. H., Feder, G. L., \& Finkelman, R. B. (1999). A possible link between Balkan Endemic Nephropathy and the leaching of toxic organic compounds from Pliocene lignite by groundwater: preliminary investigation. International Journal of Coal Geology, 40, 237-252.

Orem, W. H., Tatu, C. A., Feder, G. L., Finkelman, R. B., Lerch, H. L., Maharaj, S. V. M., et al. (2002). Environment, geochemistry and the etiology of Balkan endemic nephropathy: Lessons from Romania. Facta Universitatis, 9, 39-48.

Orem, W. H., Tatu, C. A., Lerch, H. E., Maharaj, S. V. M., Pavlovic, N., Paunescu, V., et al. (2004). Identification and environmental significance of the organic compounds in water supplies associated with a Balkan endemic nephropathy region in Romania. Journal of Environmental Health Research, 3, 53-61.

Pavlovic, N. M., Orem, W. H., Tatu, C. A., Lerch, H. E., Bunnell, J. E., Feder, G. L., et al. (2008). The role of lecithin cholesterol acetyltransferase and organic substances from coal in the etiology of Balkan endemic nephropathy: A new hypothesis. Food and Chemical Toxicology, 46, 949-954.

Pavlovic, N. M., Varghese, Z., Persaud, J. W., Stefanovic, V., Strahinjic, S., Savic, C., et al. (1991). Partial lecithin: Cholesterol acetyltransferase (LCAT) deficiency in Balkan endemic nephropathy. Kidney International, 40(34), S102S104.

Petkova-Bocharova, T., Chernozemsky, I. N., \& Castegnaro, M. (1988). Ochratoxin A in human blood in relation to Balkan endemic nephropathy and urinary system tumors in Bulgaria. Food Additives and Contaminants, 5, 299-301.

Petronic, V. J., Bukurov, N. S., Djokic, M. R., Milenkovic, D. Z., Vuksanovic, A. M., Avramovic, A. D., et al. (1991). Balkan endemic nephropathy and papillary transitional cell tumors of the renal pelvis and ureters. Kidney International, 40(34), S77-S79.

Pfohl-Leszkowicz, A., Petkova-Bocharova, T., Chernozemsky, I. N., \& Castegnaro, M. (2002). Balkan endemic nephropathy and associated urinary tract tumours: A review on aetiological causes and the potential role of mycotoxins. Food Additives and Contaminants, 19, 282-302.

Piscator, M., Kostial, K., \& Plestina, R. (1984). Urinary excretion of cadmium and zinc among women with Balkan endemic nephropathy. Trace Elements in Medicine, 1, 134-138.

Plestina, R. (1992). Some features of Balkan endemic nephropathy. Food and Chemical Toxicology, 30, 177-181.

Praharaj, T., Powell, M. A., Hart, B. R., \& Tripathy, S. (2002). Leachability of elements from sub-bituminous coal fly ash from India. Environment International, 27, 609-615.

Prokop, Z., Vangheluwe, M. L., Van Sprang, P. A., Janssen, C. R., \& Holoubek, I. (2003). Mobility and toxicity of metals 
in sandy sediments deposited on land. Ecotoxicology and Environmental Safety, 54, 65-73.

Prommer, H., Aziz, L. H., Bolano, N., Taubald, H., \& Schuth, C. (2008). Modelling of geochemical and isotopic changes in a column experiment for degradation of TCE by zerovalent iron. Journal of Contaminant Hydrology, 97, 13-26.

Radovanovic, Z. (2002). Balkan endemic nephropathy in Serbia: Current status and future research. Facta Universitatis, 9, 26-30.

Radovanovic, Z., \& Krajinovic, S. (1979). The Balkan endemic nephropathy and urinary tract tumors. Archiv fur Geschwulstforschung, 49, 444-447.

Radovanovic, Z., \& Peric, J. (1979). Hydrogeological characteristics of endemic nephropathy foci. Public Health, 93, $76-81$.

Ruhl, L., Vengosh, A., Dwyer, G. S., Hsu-Kim, H., \& Deonarine, A. (2010). Environmental impacts of the coal ash spill in Kingston, Tennessee: An 18-Month Survey. Environmental Science and Technology, 44, 9272-9278.

Selinus, O. (2007). Medical geology: An opportunity for the future. Ambio, 36, 114-116.

Siavalas, G., Kalaitzidis, S., Cornelissen, G., Chatziapostolou, A., \& Christanis, K. (2007). Influence of lignite mining and utilization on organic matter budget in the Alfeios River Plain, Peloponnese (South Greece). Energy \& Fuels, 21, 2698-2709.

Siskov, G. (1997) Bulgarian low rank coals: Geology and petrology. In R. Gayer \& J. Pesek (Eds.), European coal geology and technology. Geological Society Special Publications, 125, 141-148.

Stefanova, M., Oros, D. R., Otto, A., \& Simoneit, B. R. T. (2002). Polar aromatic biomarkers in the Miocene Maritza-East lignite, Bulgaria. Organic Geochemistry, 33, 1079-1091.

Stefanovic, V. (1998). Balkan endemic nephropathy: A need for novel aetiological approaches. The Quarterly Journal of Medicine, 91, 457-463.

Stefanovic, V., Toncheva, D., Atanasova, S., \& Polenakovic, M. (2006). Etiology of Balkan endemic nephropathy and associated urothelial cancer. American Journal of Nephrology, 26, 1-11.

Suciu, E. I., Ordodi, V., Szilagyi, D. N., Tatu, C. A., Orem, W. H., Lerch, H. E., et al. (2005). Balkan endemic nephropathy etiology: A link between geochemistry and medicine. Timisoara Medical Journal, 55, 228-234.

Swaine, D. J., \& Goodarzi, F. (1995). Environmental aspects of trace elements in coal. The Netherlands: Kluwer Acad. Publ, 312 pp.

Tatu, C. A., Orem, W. H., Feder, G. L., Paunescu, V., Dumitrascu, V., Szilagyi, D. N., et al. (2000a). Balkan endemic nephropathy etiology: A link to the geological environment. Central European Journal of Occupational and Environmental Medicine,6, 138-150.

Tatu, C. A., Orem, W. H., Feder, G. L., Finkelman, R. B., Szilagyi, D. N., Dumitrascu, V., et al. (2000b). Additional support for the role of the Pliocene lignite derived organic compounds in the etiology of Balkan endemic nephropathy. Journal of Medical Biochemistry,4, 95-101.

Tatu, C. A., Orem, W. H., Finkelman, R. B., \& Feder, G. L. (1998). The etiology of Balkan endemic nephropathy: Still more questions than answers. Environmental Health Perspectives, 106, 689-700.
Tatu, C. A., Orem, W. H., Maharaj, S. V. M., Finkelman, R. B., Diaconita, D., Feder, G. L., et al. (2003). Organic compounds derived from Pliocene lignite and the etiology of Balkan endemic nephropathy. In H. C. W. Skinner \& A. R. Berger (Eds.), Geology and health: Closing the gap (pp. 159-162). New York: Oxford Univ. Press.

Toncheva, D., \& Dimitrov, T. (1996). Genetic predisposition to Balkan endemic nephropathy. Nephron, 72, 564-569.

Toncheva, D., Dimitrov, T., \& Stojanova, S. (1998). Etiology of Balkan endemic nephropathy: A multifactorial disease? European Journal of Epidemiology, 14, 389-394.

Toncheva, D., Gergov, T. D., Tzoneva, M. T., \& Bouchakliev, P. Z. (1991). Spontaneous and induced chromosome aberrations in Balkan endemic nephropathy. Kidney International, 40(34), S97-S101.

Voice, T. C., Long, D. T., Radovanovic, Z., Atkins, J. L., McElmurry, S. P., Niagolova, N. D., et al. (2006a). Critical evaluation of environmental exposure agents suspected in the etiology of Balkan endemic nephropathy. International Journal of Occupational and Environmental Health, 12, 369-376.

Voice, T. C., McElmurry, S. P., Long, D. T., Dimitrov, P., Ganev, V. S., \& Petropoulos, E. A. (2006b). Evaluation of the hypothesis that Balkan endemic nephropathy is caused by drinking water exposure to contaminants leaching from Pliocene coal deposits. Journal of Exposure Science \& Environmental Epidemiology, 16, 515-524.

Voice, T. C., McElmurry, S. P., Long, D. T., Petropoulos, E. A., \& Ganev, V. S. (2002). Evaluation of coal leachate contamination of water supplies as a hypothesis for the occurrence of Balkan endemic nephropathy in Bulgaria. Facta Universitatis, 9, 128-129.

Vukelic, M., Sostaric, B., \& Belicza, M. (1992). Pathomorphology of Balkan endemic nephropathy. Food and Chemical Toxicology, 30, 193-200.

Wang, W., Qin, Y., Song, D., \& Wang, K. (2008). Column leaching of coal and its combustion residues, Shizuishan, China. International Journal of Coal Geology, 75, 81-87.

Wedeen, R. P. (1991). Environmental renal disease: Lead, cadmium and Balkan endemic nephropathy. Kidney International, 40(34), S4-S8.

Whitehurst, D. D. (1978). A primer on the chemistry and constitution of coal. In: Larsen, J.W. (Ed.), Organic chemistry of coal (pp. 1-35). ACS Symposium Series 71, American Chemical Society, Washington, DC.

Wilson, R., Colome, S. D., Spengler, D., \& Wilson, D. G. (1980). Health effects of fossil fuel burning. Cambridge, MA: Ballinger. 392 pp.

Wright, D. J., Pedit, J. A., Gasda, S. E., Farthing, M. W., Murphy, L. L., Knight, S. R., et al. (2010). Dense, viscous brine behavior in heterogeneous porous medium systems. Journal of Contaminant Hydrology, 115, 46-63.

Yuan, C.-G., Li, Q.-P., Feng, Y.-N., \& Chang, A.-L. (2010). Fractions and leaching characteristics of mercury in coal. Environmental Monitoring and Assessment, 167, 581-586.

Zhang, W., Lin, X., \& Su, X. (2010). Transport and fate modeling of nitrobenzene in groundwater after the Songhua River pollution accident. Journal of Environmental Management, 91, 2378-2384.

Zhao, Z.-B., Liu, K., Xie, W., Pan, W.-P., \& Riley, J. T. (2000). Soluble polycyclic aromatic hydrocarbons in raw coals. Journal of Hazardous Materials B, 73, 77-85. 